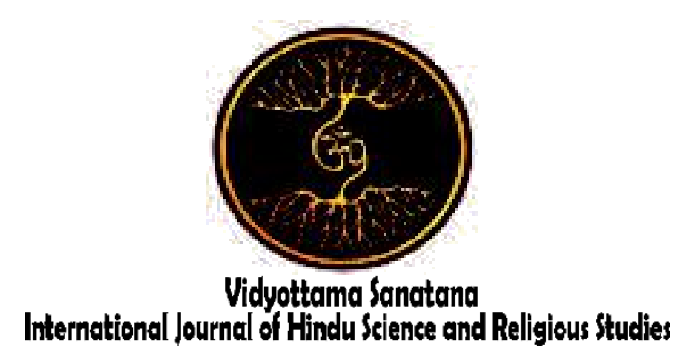

Vol. V No. 1 June 2021

\title{
HINDU SOCIETY PERCEPTION OF CATUR VARNA IN BALI
}

By:

Ida Bagus Subrahmaniam Saitya ${ }^{1}$, Ida Bagus Putu Adnyana ${ }^{2}$

Universitas Hindu Negeri I Gusti Bagus Sugriwa Denpasar

Email: tugusbramsaitya@uhnsugriwa.ac.id

Received: March 01, 2021

Accepted: June 30, 2021

Published: June 30, 2021

\begin{abstract}
The social life of the Hindu community in Bali cannot be separated from the ins and outs of work which then reflects the profession of the people who claim it. Professions in the social life of society will give birth to something called the professional group. This professional group will then have a social impact in the form of life strata in society. There is a separation between one profession and another, which then gives birth to a concept of ideas called the Catur Varna. In recent years there has been a widespread dualism of perspectives on the meaning of this Catur Varna concept. Some of them stated that this concept was a tradition passed down from generation to generation and there were also those who stated that this concept was an idea to organize the social life of Balinese people. The Catur Varna concept itself can be understood through literature which gives birth to a reality and facts. The concept of Catur Varna has been degraded due to the cognitive bias of the Balinese Hindu community in Bali in embodying the meaning of this concept. So that this concept does not give birth to social life that is more organized but instead creates a social problem that causes inequality in the body of community life. This inequality must be corrected immediately so that it does not become a tradition that has increasingly worsened the atmosphere of social life in Bali. Because today the concept of Catur Varna is consciously shifting meaning into a new concept that we have previously called the term Catur Kasta.
\end{abstract}

Keywords: cognitive bias; catur varṇa; catur kasta 


\section{INTRODUCTION}

Hinduism in most of its literary works describes aspects of divinity. The divine aspect in question gave birth to a socio-religious teaching. It is intended that human social life cannot be separated from theological values and can free humans from the virtual shackles in the world. Social life is closely related to the process of interaction between humans and other humans. This social interaction then gives birth to a system of mutual need for each other, so it will be very difficult if humans live without help from other humans. This is what social scientists call homo socius (humans as social beings).

According to Sanjaya and Rusdi (2012:26) social interaction is a reciprocal relationship, influences each other in thoughts and actions, and cannot be separated from a relationship that occurs between individuals, socially and society in everyday life. So that it is necessary to properly maintain relationships between humans in order to create a harmonious life. In Hinduism, maintaining a harmonious relationship between humans is called pawongan, which is part of the Tri Hita Karana teachings. Besides pawongan, humans must also maintain a hormonal relationship with God (Parhyangan) and the Environment (Palemahan). A harmonious relationship is certainly born from a very good arrangement of community life. The Balinese people in maintaining harmony in social life use the concept of Catur Varna to regulate unity in coexistence.

The concept of Catur Varna in Hindu society in Bali has experienced a very concerning degradation of meaning. This degradation gives rise to a negative statement that it is not true varna but caste / dynasty. This kind of problem needs to be straightened out so as not to raise new problems in the future, considering that this caste / dynasty system has become a tradition and is a family legacy from century to century. Traditions that are considered to be wrong must be clarified in order to obtain the real truth. Such as the statement of Krṣna's avatara to Bīsma that tradition is like a mango. At first the mango fruit is bitter and causes no one to like it, but over time it becomes sour and everyone starts to enjoy it, and in the end the mango fruit becomes sweet so everyone loves it. But then the mangoes will rot. The person who knows the truth will not eat the mango that is rotten, but for the person who is ingrained about mango inside, he will still eat the mango. This is the same as tradition, that traditions that are outdated or are no longer relevant to the dynamics of life in the present era and are not in accordance with the holy teachings in the scriptures, must be renewed. Now the problem is how to change this tradition and have a positive impact on the life of the Hindu community in Bali. This study aims to answer this problem through a literary perspective in order to change the mindset of the Hindu community in Bali regarding the caste / wangsa system which is actually something that must be corrected.

The theory used in this research is symbolic interaction theory. Symbolic interaction theory is a theory that has a perspective that humans create essence through the communication process. Symbolic interaction theory focuses on the importance of self-concept and opinions or perceptions held by individuals based on relationships with other individuals.

The self-concept that shapes the interactions between individuals will give birth to a stratum in society. Chaplin in (Pardede, 2008:147) suggests that self-concept is an individual evaluation of oneself; assessment or self-assessment by the individual concerned. The self-concept is formed because of the interaction with the people around him. What other individuals perceive about themselves cannot be separated from the structure, role, and social status of an individual (Papalia, Olds, and Feldman in Pardede, 2008:147).

Normatively, the self-concept will provide a perception to the Hindu community in Bali about Catur Varna. This self-concept will provide a reflection to each individual that communication is very important to overcome misperceptions in understanding every culture that enters. 


\section{METHOD}

The research approach used is qualitative research that rests on an interpretive paradigm so that it views social reality as something holistic or whole and the paradigm of critical social theory. Basically, social reality will give birth to social construction. Social construction is a statement of belief (a claim) and also a point of view (a viewpoint) that the content of consciousness and how to relate to other people is taught by culture and society. Social construction is a view to us that all values, ideologies, and social institutions are manmade (Ngangi, 2011: 1).

The object of study is the Hindu community in Bali in living their social life. The Hindu community in Bali is positioned as an object of research on an issue that is currently very concerning about the cognitive bias of the meaning of Catur Varna. This research was conducted as a text reference material to read hermeneutically critical, including the deconstruction method in order to understand denotative and connotative meanings in order to be separated from absolute assumptions.

\section{RESULTS AND DISCUSSION}

Hindu religious teachings have a perspective on society as something born from God. Thus, society in the Hindu perspective is a normative system in accordance with systems theory. The Vedic scriptures, in this case Śruti, states that society is born from cosmic humans. Cosmic humans are humans who cover the universe. What is meant here is God or Ida Sang Hyang Widi Wasa himself. God is the source of human social life in the world, because God plays an important role in the process of creating social strata in society. This social stratum gave rise to a concept known as Catur Varna. Since ancient Balinese times, Catur Varna has been mistaken for the meaning of Caste / Wangsa.

Agung in Hardy, Setiawan, and Prayitno (2016: 82) states that Catur Varna consists of two words, namely catur which means four, and varṇa or vri which means choosing a job. Thus, Catur Varna is understood as a system of dividing society into four groups or groups based on the concept of dharma or swadharma, namely according to obligations, talents, or types of work. Meanwhile, catur wangsa or catur jatma is a system of dividing society into four groups based on the concept of jati (jan: birth), which is according to lineage or birth. This is why the term catur wangsa is often confused with caste related to descent or race.

A person has a caste judged from which family he is born. In addition, caste can change if a person marries or marries with a higher or lower caste. Marriage is an individual action in society which means that there is a transition from the adult level of life to the level of family life. This action is one of a number of events that are passed in the life cycle (Sudarma, 2015: 158).

According to Sudarma (2015: 161), interwangsa marriages in Bali still show discriminatory treatment, although not as cruel as the kingdom. Prior to 1951, inter-wangsa marriage was an obstacle and was even considered a violation of the law. The violations referred to are violations of the asupundung and alangkahi karanghulu customs. Asupundung is a custom offense if a male jaba wangsa marries a woman from the brahmana wangsa. On the other hand, alangkahi Karanghulu is the custom offense of a man who jaba wangsa married a ksatriya wangsa. The two offenses for the marriage custom were in effect at the beginning of the XIX century.

If you pay attention to the context, there is no difference between parts of the concept of Catur Varṇa and Caste / Catur Wangsa, but what becomes a concern is the meaning of the teaching concept which is misinterpreted. Catur Varna emphasizes the division of society based on profession, but it differs from caste / dynasty chess which emphasizes the division of society's composition or social strata based on heredity, in other words a person's varna is carried from the time he is born into the world and determined in which family he is born in. Caste / Catur Wangsa are four systems of classification of society based on the profession they are engaged in and are not satis or can change at any time. In the 
concept of the Catur Varna teaching, the classification of society can change according to their function and profession so that this classification is not inherited or passed down from one generation to another. This means that if the parent is a brahmin then the offspring is not necessarily a brahmin either. Catur Varna itself is divided into four important parts, the first is the Brahmana (people who pursue spiritual and divine knowledge to provide spiritual guidance and lessons). Examples are clergy, sulinggih, pandita, pinandita, and so on. Then the second is Ksatriya (people who struggle in the fields of state defense and security and government). Examples are police, soldiers, presidents, kings, and so on. The third is Waisya (people engaged in the economy to regulate social functions in driving the economy). Examples are entrepreneurs, traders, investors, and so on. Then the last one is Sudra (people who work rely on physical or physical services to make ends meet). Examples are employees, private employees, laborers, and so on. This opinion is supported by a statement (Hardy, Setiawan, and Prayitno, 2016: 82) that according to the Catur Varna system, society is divided into four groups or groups based on obligations, talents, or occupations, namely (1) Brahmins are groups of people who are obliged in the field of religion and scientific development, such as: priests, sulinggih, or clergy; (2) ksatriya is a group of people who have obligations in government and military fields, such as: kings, courtiers, or officials; (3) waisya is a group of people who have obligations in the field of community welfare, such as: traders; and (4) Shudras are groups of people who are obliged to assist the Brahman, Ksatrya, and Wesya groups, such as workers and laborers.

It is different from the concept of the caste / Catur Wangsa teaching which generalizes varna as something that is obtained based on heredity, so that someone who is born from a brahman family, for example, directly the child born has varna as a brahmin as well or is called the brahman caste. This kind of thing is not true, so there must be a supporting source that is able to provide an understanding to the public about the absolute truth of this Catur Varna concept.

The struggle to restore the purity of the teachings of Catur Varna has been carried out by many Hindus. The struggle was carried out by both scholars and through various Hindu organizations/institutions. Although it is very tough, the struggle to restore the truth of the teachings of Catur Varna has already shown results. As in the fields of government, politics, economics and law, equality is increasingly visible. Precisely in the religious and sociocultural fields, such as social relations in society, discriminating against Wangsa or Soroh is still very strong. In everyday language, it is very clear that the use of the wrong Wangsa system is used by Hindus. Likewise, in the field of religion and customs, the dynasty is still very strong. This has become a source of endless conflict in the religious life of Hindus in Bali.

The concept of caste / Catur Wangsa in the Hindu community in Bali itself has been ingrained, so that many of the social life of the community demean one another just because their caste is higher so that it is easy to lower the caste that is below it. If all people understand that God resides in every living being then this sort of thing will never happen. People will not have the heart to hurt others because they realize that hurting others is tantamount to hurting God. It is very unfortunate that today many people are impatient in dealing with emotional turmoil and lust for more than others, so that all means are done to get what they want. Instead of the harmony created in social life in society, however, it is the law of the jungle that continues to grow and become rampant. The strong prey on the weak, the rich trample the poor, the smart fool the fool, so that disputes continue from time to time. Yet if people want to understand carefully that in themselves and in others there is God who resides in it, then this kind of thing will certainly not happen. As quoted in the sacred text Bhagavadgītā XIII.28 as follows:

samaì paśyan hi sarvatra
samavasthitam ìśvaram,
na hinasty ātmanātmānà̇
tattoo yāti parāim gatim.


Translation:

Because, he who sees the Almighty residing everywhere, does not hurt the soul with the soul, so he also achieves the main goal. (Pudja, 2013:336).

This verse clearly illustrates that humans must contemplate themselves to find out how the essence of being an ideal human being in order to avoid hurting each other. The Hindu community in Bali must know how the origin of the Catur Varna concept can be present in the social strata of society. In essence, the teachings of Catur Varna have been explained in the Bhagavad Gita holy book and Hindu religious figures state that the concept of Catur Varna teachings is widely available in the sacred Vedic libraries. Meanwhile, the teachings of caste / Catur Wangsa are not described in any of the sacred Vedic literature. According to Purana (2016:188) the social exclusion of society vertically like caste is actually not known in Hinduism. This was emphasized by I Gusti Agung Gde Putra (Director General of Hindu and Buddhist Guidance at the Department of Religion) in the Bali Post, January 26, 1988 that "In the body of Hinduism there is absolutely no caste division. The term caste that has been known to the public, such as brahman, ksatriya, vaisya, and sudra is varna or the function of each member of society. The Catur Varna System is basically clearly regulated in the sacred literature of Bhagavadgitā IV.13, as the following verse describes:

cātur-varnyyam mayā srş̧tāim

guṇa-karma-vibhāgaśah,

tasya kartāram of firemām

viddhy akartāam avyayam.

Translation:

Caturvarna (four orders of society) is My creation according to the division of qualities and labor; but know that even though I am the Creator, I do not act and change myself (Pudja, 2013:113)

In the verse above, we can clearly conclude that what exists is Catur Varna, not caste / Catur Wangsa. So that the Hindu community in Bali needs to be aware of this and immediately correct any ingrained mistakes. Because if this error is allowed to continue, it will cause misunderstandings that can harm the social order of society. Such as the emergence of social intolerance and disharmony between one caste and another.

According to Purana (2016: 189) as a result of the political order and democratic government under the auspices of the Unitary State of the Republic of Indonesia, caste loses its aura and becomes nothing more than a mere designation of wangsa, citizen or cheer. Even if the titles of nobility are still in use, all of them are just names, as a sign of a certain cheer or clan that does not have any privileges or privileges, but its influence on some Balinese manners is still gripping until now.

The Catur Varṇa System is actually created or designed for the evolution of society or humans so that their concept of life is more organized. This very ideal concept of life was applied in the XI century, which aimed to organize the life of Hindus in Bali. In that century Mpu Kuturan accompanied the king in managing the life of Hindus in Bali. In the Mpu Kuturan lontar it was stated that Mpu Kuturan advised the king to organize life in Bali, "Manut Lingih Sang Hyang Aji", which means organizing life based on the teachings of the holy book (Purana, 2016: 68).

In the realization process, there is a contradiction between the implementation of Catur Varna in Bali and India. In fact, the concept of Catur Varna is not wrong, but what is wrong and distorted is its implementation in society. These problems cannot be separated from the habits of the Hindu community in Bali that lack of understanding of a culture, so that it creates a cognitive bias in accepting new cultures that enter their area of life.

In the context of Hindu theology the concept of the teachings of Catur Varna is also explained in the Yajur Veda. In the book is explained about howthe process of creating the Catur Varna concept according to the profession he is engaged in. There are many verses that explain it and all of them pay attention to a professional order, not tradition or heredity. This 
correlates with the process of the creation of the Catur Varna system by God, as described in the holy book Yajur Veda XXXI.11 as follows:

Brāmano asya mukham āsid bāhū rājanyah ktah, śrī tadasya yad vaisyah padbhyāim sudro ajāyata.

Translation:

Brahmin created through the mouth of Almighty God, ksatriyas are born from His arms, vaisya are born from the thighs (abdominal support), and sudras are born from His feet (Donder and Wisarja 2011: 34).

Catur Varna created from a part of God's body which actually contains many profound meanings. Each part has an irreplaceable function and task, so that if one of these parts is lost, the social strata of society will be disrupted and it is not impossible to experience dysfunction. The duties and functions of each section then form a population of people who each have the same class in society. However, populations with one another should not touch each other because they already have limitations in acting. The Yajur Veda scriptures explain the duties and functions of the four sections of Catur Varna. The division is explained through the mantra Yajur Veda XXX.5, as follows:

Brāhmane brāhmanam kstrāya rājanyam, Marudhbyo vaisyam, tapase sudram.

Translation:

God Almighty has created brahmins for knowledge, ksatriyas for protection, vaisyas for commerce, and shudras for physical work (Donder and Wisarja 2011: $34)$.

God through the sacred literature that He revealed to Sapta Rsi gave humans a reflection to continue to improve themselves through sadhana teachings. So that the Hindu community in Bali needs to realize the truth of the essence of this Catur Varna. People must start to be literate about the correct understanding of the concept of Catur Varna.
So it is no longer familiar with the caste system but what is known is the varna system.

\section{CONCLUSION}

The perspective of the Hindu community in Bali regarding the concept of Catur Varna has experienced a cognitive bias into caste / Catur Wangsa. This demands an alignment of the true meaning, so as to prevent regenerating misunderstandings. This teaching of Catur Varna has been written in the sacred Vedic literature such as Bhagavadgìtā and Yajur Veda Samhita, so that Balinese people need to be more profound and complex in addressing the concept of Catur Varna. So that there are no more misinterpretations in addressing Catur Varna instead of caste / Catur Wangsa.

To change the way of thinking of Hindus in Bali on the deviation of understanding about Catur Varna cannot be done directly, but gradually. There is a Hindu teaching called Vasudhaiva Kutumbakam which is a Sanskrit expression meaning that the whole world is one single family. From these Hindu teachings, it can be used as a true understanding of Catur Varna without any deviation.

\section{REFERENCE}

Donder, I.K \& Wisarja, I.K. (2011). Teologi Sosial. Surabaya: Pāramita.

Hardy, I.G.N.W., dkk. (2016). Pengaruh Sistem Catur Wangsa terhadap Perwujudan Tata Spasial Kota Peninggalan Kerajaan Hindu di Bali: Kasus Kota Karangasem. Yogyakarta: Universitas Gadjah Mada.

Ngangi, C.R. (2011). Konstruksi Sosial dalam Realitas Sosial. https://ejournal.unsrat.ac.id/index.php/jise p/article/download/85/81 (diakses pada tangal 25 Juni 2019 pukul 22.16 wita).

Pardede, Y.O.K. (2008). Konsep Diri Anak Jalanan Usia Remaja. Bandung: Fakultas Psikologi Universitas Gunadarma.

Pudja, G. (2013). Bhagavadgītā (Pañcama Veda). Surabaya: Pāramita.

Purana, I.M. (2016). Konsep Kasta Dilihat Dari Kaca Mata Idiom Estetika Postmodern. Denpasar: Jurnal Kajian Pendidikan Widya Accarya FKIP Universitas 
Dwijendra.

Purana, I.M. (2016). Pelaksanaan Tri Hita Karana dalam Kehidupan Umat Hindu. Denpasar: Jurnal Kajian Pendidikan Widya Accarya FKIP Universitas Dwijendra.

Sudarma, I.P. (2015). Bias Gender dalam Perkawinan Beda Wangsa pada Masyarakat Hindu di Bali. Denpasar: Institut Hindu Dharma Negeri (IHDN) Denpasar.

Sanjaya, A. \& Rusdi, I. (2012). Hubungan interaksi Sosial dengan Kesepian Pada Lansia. Medan: Fakultas Keperawatan Universitas Sumatera Utara. 